\title{
STRATEGIC PLANNING OF INDONESIAN SKINCARE CLINICS
}

\author{
Fajartriyani Aulia Putri, Raharja Sam’un Jaja, Dai Ratna Meisa, Hardinata Cosvi \\ Department of Business Administration, University of Padjadjaran, Indonesia \\ *E-mail: aulia17007@mail.unpad.ac.id \\ ORCID 0000-0001-9980-7995
}

\begin{abstract}
Business activity is one of the important activities within the company. The tendency of an effort to be superior to the competitors is the main target of all business units. We need strategic planning that can support the achievement of company goals. Good management of this business creates a high-profit business; therefore the business strategy development is needed. To determine and develop the strategy, SWOT analysis is needed. The unit of analysis of this research is Rafa Health and Beauty Lifestyle Aesthetic Clinic in Bandung. The method used is qualitative descriptive by analyzing the business environment from internal and external aspects. The internal analysis uses McKinsey's 7S and external analysis using Porter's five forces. After that, the analysis technique uses the SWOT matrix with the EFAS and IFAS approaches. The results show that the Rafa Aesthetic Clinic is in Quadrant II, which is the right strategy implemented is a turn-around strategy (Retrenchment) that is designed to strengthen the basic competencies of a unique organization.
\end{abstract}

\section{KEY WORDS}

7S McKinsey framework, five forces Porter's; SWOT analysis, skincare clinics.

Small and medium enterprises are always faced with uncertain market conditions, always growing rapidly to make the competition very competitive. One form of small and medium enterprises that are growing rapidly now is the beauty clinic business. Some beauty clinics that are now often found in big cities are beauty clinics that combine facial and body beauty services, and skin health consultations. Bandung is a city with a large beauty product market, based on data from the data (Bandung City Central Bureau of Statistics, 2017) also seen from the population of women aged 15-64 years, as many as 887,456 people or $49 \%$ of the population of Bandung in 2018, which is the target market of the beauty industry. This situation becomes a great potential that is utilized by the beauty industry services in the city of Bandung. The tendency of women to beautify themselves is closely related to the needs of women to come to beauty clinics.

The beauty clinic offers services by combining facial and body beauty services, and skin health consultations. Seen in figure 1 several beauty clinic practitioners in Bandung:

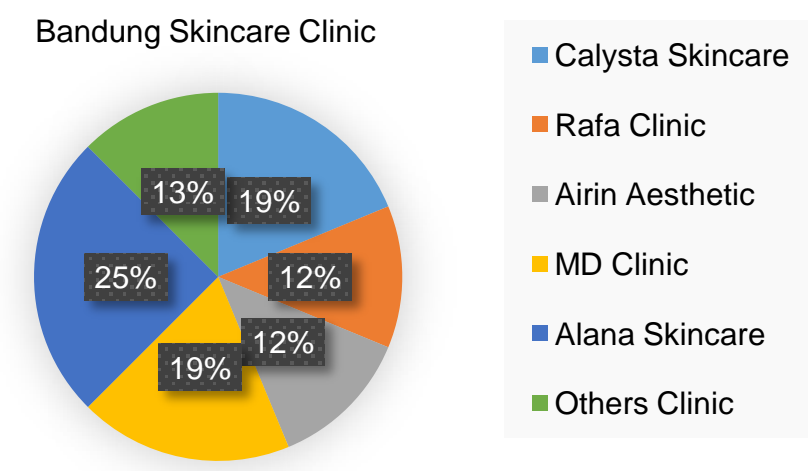

Figure 1 - Beauty clinic company in the city of Bandung 
Based on figure 1 above, it appears that several skin care industry players in the city of Bandung have two to four branches. Alana Skincare is a market leader in beauty clinics in the city of Bandung with the most branches, which has four branches. Viewed from the number of branches, length of stay, results of care, and market share. Competition between beauty clinics is getting tighter because it raises an innovation in the world of beauty in the city of Bandung. The innovations include several beauty clinics that have used sophisticated and modern tools to be used in dealing with facial problems and beautifying their consumers. Among the skincare clinics above, Rafa Clinic is one of the techniques that have more than one branch, namely two branches in the city of Bandung. At present one of the cities that has become a trend in the beauty industry is the city of Bandung. Competition between beauty clinics in the city of Bandung is very strict accompanied by fashion trends among women is increasing.

Rafa beauty clinic is located in the city of Bandung, there since 2005. Currently, Rafa clinic has 3 branches spread in Bandung and Garut. Rafa Clinic is engaged in the field of aesthetic medicine, anti-aging medicine, and herbal aesthetic. The clinic is currently supported by high-tech equipment that is always the foremost, innovative and complete in overcoming all health and beauty problems. The Rafa Clinic has a complete range of treatments ranging from toe to head. Available Medical and Non-Medical Treatments, as well as safe and clinically tested care products that are tailored to the type and problem of the skin. Accompanied by Doctors, Pharmacists, Pharmacy and Beauty Therapists who are trained, professional, experienced and certified. With the motto "Beauty Aesthetics with Smart Way", Rafa is very following the times in terms of skincare, slimming and more.

Consumers will be more selective in choosing a beauty clinic that will be a place to subscribe, by looking at the services provided. Because, good service is also an important thing in the success of the beauty business. Rafa Clinic always strives to provide the best service for its consumers, but more and more competitors also provide different services for their customers. Also, consumers will choose beauty clinics that can provide cheaper prices with services that are not reduced at all. There is a problem with the Rafa Clinic compared to other skin care clinics, that is, every consumer is charged a fee when consulting a beauty doctor, but at several other beauty clinics, the consultation process is free. Consumers also become more selective in choosing cheaper prices with the same quality products and services, because consumers prefer services and products at the lowest possible prices.

Every company will try to compete with other companies that produce replacement products. With its ability to satisfy needs that are not much different from consumers, but with different characteristics, the price of a substitute product can be the highest limit of the price set by a company. Thus, a replacement product performs the same or similar function or service. This is certainly a pretty heavy problem faced by the Rafa Clinic. Some examples of beauty products that can replace Rafa Clinic products are Ashanty Beauty Skincare, Ertos facial treatment, Helwa Beauty, EMK Beverly Hills, and Dissy Cosmetics.

If you look at the problems faced, there is a need for a strategic planning analysis that will certainly strengthen the existence of the Rafa Clinic to keep attracting public attention. The identification is in line with what was revealed (Porter, 1980, 1996,1997) (Rulmet, 1984) there are five competitive forces in an industry, namely the threat of the entry of new entrants, the threat of substitute products, the bargaining power of buyers, the strength of supplier bargaining power, competition among competitors. These five competitive forces determine the intensity of competition and profitability in the industry and will be very important in the formulation of the company's strategy. The state of competition in an industry depends on the five competitive forces.

This research was conducted by analyzing the strategic planning that will be carried out by the Beauty Clinic by using the analysis of Five Forces Porter and 7S McKinsey, then analyzed through external factor analysis strategy (EFAS) and internal factor analysis strategy (IFAS) with approaches to strengths, weakness, opportunities and threats (SWOT) analysis. With this analysis, it is hoped that it will produce further identification of the formulation of competitive strategies that can be done by the Rafa Clinic to continue to exist in a society that has cared a lot about appearance, especially skin and body beauty. 


\section{LITERATURE REVIEW}

Business strategy is a comprehensive planning formula on how the company will achieve its objectives, taking into account its internal and external environment to maximize competitive advantage and minimize competing limitations (Rumelt, Schendel, \& Teece, 1991; Teece, 2010). Strategic planning is part of strategic management. Strategic planning focuses on how top management determines the company's strategy to achieve company goals in the long run (Thune \& House, 1970; Wheelen \& Hunger, 2010). Strategic planning is a systematic effort something formal from the company, to describe the main form of the company, objectives, policies, and strategies, to achieve the target and the main form of the company concerned in managing the company today to do future projections (Kerzner, 2001; 2004).

Strategic planning is an effort made by a company to develop the company's vision and mission, culture, and business strategies needed to be implemented to achieve the company's targets (Haines, 2010). Strategic planning as a way to determine fundamental decisions to form and guide an organization with the aim of what must be done (Bryson, 1988). In preparing strategic planning, it is necessary to formulate the goals and objectives to be achieved by the company. The essence of strategic planning is knowing the opportunities and threats in the future, with the choice of steps needed and more appropriate to achieve the desired situation explicitly related to management of change and includes a series of innovations and changing companies (I. Ansoff, 1965; 1968; 2005; Simons, 1994; Rulmet, 1984; Ginsberg \& Venkatraman, 2011; Nickols, 2016; Dey, Clegg, \& Bennett, 2010).

The 7S framework was developed in the early 1980s by Tom Peters and Robert Waterman. There are 7 factors which are interdependent, each grouped into Soft \& Hard elements. Soft Elements is more difficult to describe, less tangible and influenced by culture, namely: Shared Values, Skills, Style, and Staff. Hard Elements is easier to define and determine and management can directly influence it, namely: Strategy, Structure, Systems. 7S from McKinsey or better known as McKinsey 7S Framework is a management model to see how effective the organization is in achieving its desired goals (Savkin, 2015; Kaplan, 2005).

According to (Porter, 2008a; 2008b) there are five competitive forces in an industry, namely the threat of the entry of new entrants, the threat of substitute products, the bargaining power of buyers, the strength of supplier bargaining power, competition among competitors. These five competitive forces determine the intensity of competition and profitability in the industry and will be very important in the formulation of the company's strategy. According (David \& David, 2017) the steps taken in the formulation of the strategy for the main stage are the formulation of a strategy consisting of IFAS (internal factor analysis strategy) is a strategy formulation tool used to summarize and evaluate the main strengths and weaknesses in the scope of business functions, and also becomes the basis for identifying and evaluating the relationships between these areas, then EFAS (external factor analysis strategy) that enables strategy makers to summarize and evaluate political, economic, socio-cultural, and technological information. A thorough understanding of the factors included in it is more important than the numbers available.

In general, companies must monitor the strength of the macro environment (demography, economy, technology, politics, law, and social culture) and microenvironmental actors (consumers, competitors, distribution channels, suppliers) that affect the ability to earn profits. Companies must have marketing intelligence capabilities to follow trends or developments, management needs to identify opportunities and threats posed (Rangkuti, 2013).

According to (Rangkuti, 2015) explained that SWOT analysis is the identification of various factors systematically to formulate a company's strategy, based on a logic that can maximize strengths and opportunities, but simultaneously minimize weaknesses and threats SWOT analysis has important roles and functions in the planning process and strategic decision making. A SWOT analysis is an integrated analysis framework between internal companies and the external environment, by building a SWOT approach. A SWOT analysis 
is also a tool to identify whether the strategic decisions that have been taken or determined are correct or not (Assauri, 2011). From the analysis, an overall picture of the general condition of the company will be obtained. The results of the analysis are expected to help companies improve their competency and capability (Wheelen \& Hunger, 2010).

\section{RESEARCH FRAMEWORK}

The Strategic Planning Analysis Process of Beauty Aesthetic Clinic Rafa Health and Beauty was conducted through a series of analyzes, which began with identifying the vision and mission of the Rafa Skincare Beauty Clinic. Then proceed by analyzing external environmental factors and internal environment. External environment analysis in the form of opportunities and threats using Five Forces Porter. While the analysis of the internal environment in the form of strengths and weaknesses of the company (7s Mckinsey). After identifying the vision and mission and analyzing the environmental situation, the two steps are needed to formulate a strategy, at this stage, there are two steps in determining the strategy.

First, determine the alternative strategy using the SWOT matrix. After the strategy is obtained, the next stage is the formulation of long-term goals and objectives. From the results of the strategy formulation, there will be strengths and weaknesses, and what opportunities and threats will be faced by the Rafa Health and Beauty Aesthetic Beauty Clinic in Bandung City. This will be a reference material that will strengthen and clarify the direction of the goals and objectives to be achieved in the next five years.

Based on the strategies generated from the above steps and by taking into account the vision and mission, environmental factors, and goals and objectives, strategies, programs, and action plans can be established to support the competitive strategy of Rafa Health and Beauty's Aesthetic Beauty Clinic in Bandung. This research framework is listed in Figure 2.

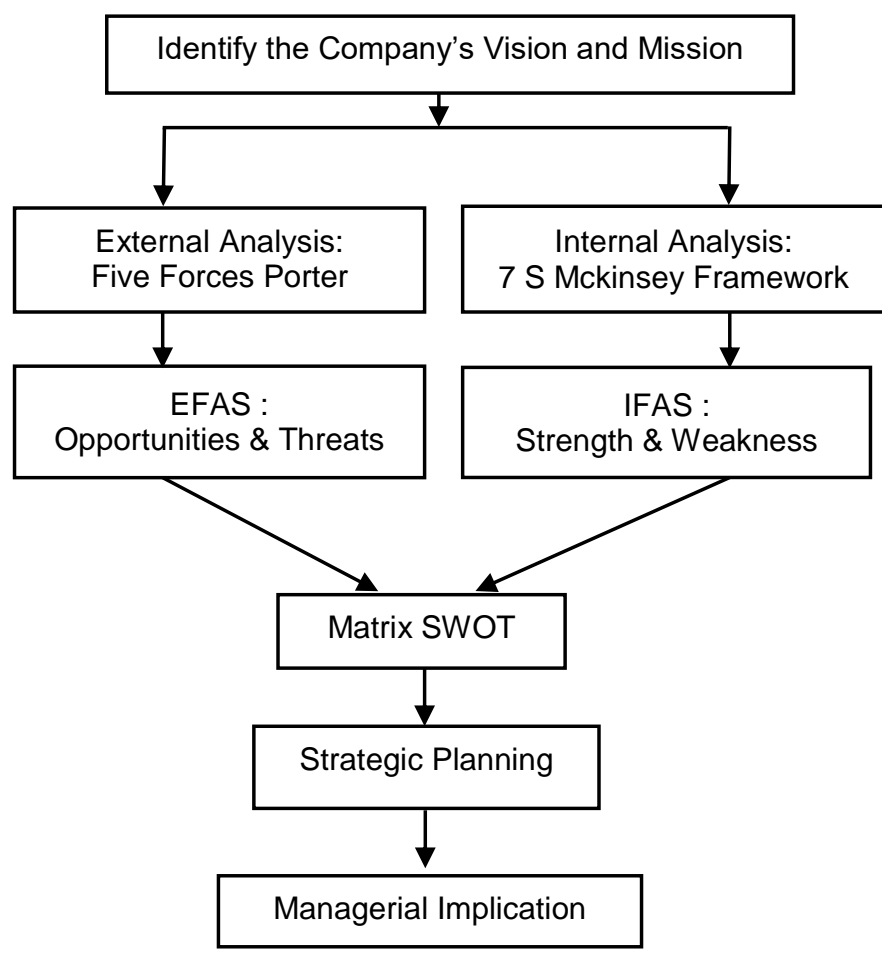

Figure 2 - Research Framework

\section{METHODS OF RESEARCH}

The research method that will be used is qualitative with in-depth exploration (Gunawan, 2013) about the object of research, namely SWOT analysis at the Rafa Health 
and Beauty Lifestyle Beauty Clinic. The basis of the theoretical foundation of qualitative research rests on phenomenology and excavation of meaning in research. In a qualitative approach, the position of the theory is an end product that must be produced. The research design is built on a set of assumptions and concepts developed from relevant theories that exist.

The informant's sources in this study were from the Rafa Beauty Clinic to get information about the company's Vision and mission, to know the circumstances of internal environmental factors and external factors, then to find out the level to meet the interests of the SWOT attribute. Then the party from the Bandung Small and Medium Enterprises Cooperative Office, to get data on the number of units and the value of contributions and how the growth rate of the Bandung City beauty clinic.

The researcher used the technique of checking data validity (trustworthiness) put forward by (Sugiyono, 2010; 2016) including the test of credibility, transferability (external validity), dependability (reliability), and confirmability (objectivity). After the data is valid, then the data presented by the researcher is obtained from the results of observations and interviews consisting of an analysis of five forces porters which will be an external environmental factor, and 7S McKinsey which is an internal environmental factor. Furthermore, these factors will be further analyzed based on the SWOT matrix assessment. Matix SWOT is processed based on EFAS (External factor analysis strategy) and IFAS (Internal factor analysis strategy). Strategy analysis through the SWOT matrix is a technique that can objectively establish priority strategies that are prioritized, as a technique that aims to determine business strategies in Beauty Clinics, analysis to determine business strategy requires good intuitive judgment. So this study uses a qualitative approach with the technique of in-depth interviews with informants.

\section{RESULTS AND DISCUSSION}

According to (Pearce \& Robinson, 2011), a strategy is a large-scale plan that is longterm oriented to interact with a competitive environment to achieve company goals. Strategic analysis is carried out to gather information from informants who will form the basis of strategy formulation. According to (Tunggal AW., 2009) explained that business strategy is a strategy that must be made as to the main thinking base in making information technology strategies because in the strategy mentioned the company's vision and mission along with the performance targets of each function and organizational structure. According to (Ward \& Peppard, 2002), business strategy is a solution that aims to achieve long-term goals. Business strategies are formulated to determine how an organization becomes more competitive than its previous position (Rumelt, 2012; Rumelt et al., 1991; Corrocher \& Guerzoni, 2009; Ginsberg \& Venkatraman, 2011; Slater \& Narver, 1994; Thune \& House, 1970; Chang \& Horng, 2010).

According to (David, 2011; David \& Carolina, 2011) the process of formulating a company's strategy includes three stages, namely; input stage, matching stage and decision stage. The input stage contains basic input information needed to formulate a strategy. The matching stage focuses on creating alternative strategies that make sense by taking into account the main internal and external factors. The decision stage serves to objectively evaluate alternative strategies identified at the matching stage and provide an objective foundation for the selection of alternative strategies. Strategy analysis is an evaluation of internal factors (IFAS) and external factors (EFAS) of the Beauty Clinic. Internal environmental factors in the form of strengths and weaknesses were analyzed through 7S McKinsey (Waterman, Peters, \& Phillips, 1980; Kaplan, 2005; Savkin, 2015; Fleisher \& Bensoussan, 2007; Ravanfar, 2015; 2017). External environmental factors in the form of opportunities and threats obtained based on the analysis of five forces porters (M E Porter, 1979; 2008) at the Rafa Clinic Beauty Clinic. After that, then the results of IFAS and EFAS analysis become a reference for the formulation of the SWOT Matrix (Rangkuti, 2015) too produce a business position Quadrant thatcano create alternative strategies for the Rafa Clinic Beauty Clinic. 
For internal analysis, this study utilizes McKinsey's 7s framework of Strategy, Structure, Systems, Skills, Style, HR, and Value. By using this framework, analysis of internal conditions can be done in full.

Table 1 - Internal Environment Conditions

\begin{tabular}{|c|c|c|c|c|}
\hline No & $\begin{array}{c}7 \mathrm{~S} \\
\text { McKinsey }\end{array}$ & Fact & Rafa Clinic Owner Opinion & $\begin{array}{l}\text { Strengths / } \\
\text { Weaknesses }\end{array}$ \\
\hline 1 & $\begin{array}{l}\text { Shared } \\
\text { value }\end{array}$ & $\begin{array}{l}\text { Very strategic business } \\
\text { location }\end{array}$ & Making the city of Bandung a big market & Strengths \\
\hline 2 & Structure & Having a business branch & Broader business reach & Strengths \\
\hline 3 & Strategy & Cost Leadership & $\begin{array}{l}\text { Cost leadership can be used to maintain the } \\
\text { company's position }\end{array}$ & Strengths \\
\hline \multirow{3}{*}{4} & \multirow{3}{*}{ System } & Marketing limitations & $\begin{array}{l}\text { Competitors have e-commerce websites that can } \\
\text { function as sales channels to market their products }\end{array}$ & Weaknesses \\
\hline & & Limitations of raw materials & $\begin{array}{c}\text { The limitations of raw materials make the company } \\
\text { hampered in producing its products }\end{array}$ & Weaknesses \\
\hline & & Facilities and infrastructure & $\begin{array}{c}\text { Competitors have better facilities and infrastructure } \\
\text { than the Rafa Clinic }\end{array}$ & Weaknesses \\
\hline 5 & Style & $\begin{array}{l}\text { Having a work culture with a } \\
\text { family system }\end{array}$ & $\begin{array}{c}\text { Togetherness and kinship will foster a sense of } \\
\text { belonging so employees will work without feeling } \\
\text { forced }\end{array}$ & Strengths \\
\hline \multirow[t]{2}{*}{6} & \multirow[t]{2}{*}{ Staff } & Labor that is not optimal the & $\begin{array}{c}\text { the excess workload must be evaluated whether } \\
\text { due to a growing business or unclear division of } \\
\text { tasks }\end{array}$ & Weaknesses \\
\hline & & $\begin{array}{l}\text { Have special and quality } \\
\text { human resources }\end{array}$ & $\begin{array}{l}\text { HR is unique, and the company's uniqueness will } \\
\text { create a competitive advantage }\end{array}$ & Strengths \\
\hline 7 & Skill & $\begin{array}{l}\text { There are no substitute } \\
\text { specialists for beauty } \\
\text { specialists }\end{array}$ & $\begin{array}{c}\text { Companies that are unable to regenerate their } \\
\text { knowledge will become a threat }\end{array}$ & Weaknesses \\
\hline
\end{tabular}

Table 1 presents a list of internal environmental conditions of the Rafa Beauty Clinic which are grouped according to McKinsey's 7s framework. The column "Competitors / Standards / Literature / Expert Opinion / Impact" provides a brief explanation of the things that form the basis of determining whether the internal conditions possessed are a strength or weakness. The results of determining the condition are included in the "Strength / Weakness" column. Then the next analysis is an analysis of external environmental conditions using the Porter five forces approach, namely Suppliers, Customers, Competitors, New Arrivals, and Substitute Products. With this analysis, the study succeeded in identifying opportunities and threats originating from the external environment of the Rafa Health and Beauty Lifestyle Beauty Clinic.

Table 2 - External Environmental Conditions

\begin{tabular}{|c|c|c|c|c|}
\hline No & $\begin{array}{l}\text { Porter's five } \\
\text { forces }\end{array}$ & Fact & Impact on business & $\begin{array}{c}\text { Opportunities/ } \\
\text { Threats }\end{array}$ \\
\hline \multirow[b]{2}{*}{1} & \multirow[b]{2}{*}{ Supplier } & Raw material supply & $\begin{array}{c}\text { Rafa clinic only has one source of raw materials, a threat } \\
\text { to high product costs }\end{array}$ & Threats \\
\hline & & $\begin{array}{l}\text { Good relationships } \\
\text { with stakeholders }\end{array}$ & $\begin{array}{l}\text { A good relationship between the Rafa Beauty Clinic and } \\
\text { stakeholders is very necessary for the continuity of } \\
\text { business activities. }\end{array}$ & Opportunities \\
\hline 2 & Buyers & Customer loyalty & $\begin{array}{c}\text { Customer loyalty is a great opportunity to compete with } \\
\text { competitors through loyal customers. }\end{array}$ & Opportunities \\
\hline \multirow{3}{*}{3} & \multirow{3}{*}{ Competitor } & Intense competition & Threats to Rafa can develop & Threats \\
\hline & & $\begin{array}{l}\text { Business location } \\
\text { environment }\end{array}$ & $\begin{array}{c}\text { The business location environment influences consumer } \\
\text { access to repeated orders, a great opportunity for } \\
\text { sustainability }\end{array}$ & Opportunities \\
\hline & & Country economy & The threat of Rafa clinic's customers dropping & Threats \\
\hline \multirow[t]{2}{*}{4} & \multirow{2}{*}{ New Entrants } & Good market growth & $\begin{array}{l}\text { The rapid growth of the beauty industry market has } \\
\text { become an opportunity for business people in the field of } \\
\text { beauty clinics. }\end{array}$ & Opportunities \\
\hline & & $\begin{array}{l}\text { Product licensing } \\
\text { policy }\end{array}$ & $\begin{array}{c}\text { The absence of product licensing raises doubts for } \\
\text { consumers }\end{array}$ & Threats \\
\hline \multirow{2}{*}{5} & \multirow{2}{*}{$\begin{array}{l}\text { Substitute } \\
\text { Products }\end{array}$} & $\begin{array}{l}\text { Contents of harmful } \\
\text { substances }\end{array}$ & Contents of harmful substances reduce customer interest & Threats \\
\hline & & $\begin{array}{l}\text { Technological } \\
\text { sophistication }\end{array}$ & $\begin{array}{l}\text { Great opportunity to be able to compete with larger } \\
\text { competitors than Rafa }\end{array}$ & Opportunities \\
\hline
\end{tabular}


Table 2 presents a list of the external environmental conditions of Micro Rafa Beauty Clinics grouped by the framework of Porter's five forces. The "Impact on Business / Industry" column provides a brief explanation of the influence of external conditions on the company, whether it becomes an opportunity or threat. The results of determining the condition are included in the "Opportunities / Threats" column.

Based on the results of the presentation data described above, several factors are gathered which become the external environment and which become the internal environment of the Beauty Clinic Rafa Healthy Lifestyle and Beauty. The following are the internal environmental factors that have analysis at the Rafa Beauty Clinic:

Table 3 - Internal Environmental Factors

\begin{tabular}{|c|c|c|c|}
\hline \multicolumn{4}{|c|}{ INTERNAL ENVIRONMENT } \\
\hline \multicolumn{2}{|r|}{ STRENGTHS } & \multicolumn{2}{|r|}{ WEAKNESSES } \\
\hline 1 & A very strategic business location & 1 & Marketing limitations \\
\hline 2 & Competitive prices & 2 & Limitations of raw materials \\
\hline 3 & Having special and quality human resources & 3 & Facilities and infrastructure \\
\hline 4 & Having a work culture with a family system & 4 & Do not have an optimal workforce \\
\hline 5 & Has a branch & 5 & There are not many beauty specialists \\
\hline
\end{tabular}

The internal environmental factors are then included in the IFAS table to get the weight and rating that shows the importance of a factor compared to other factors. The value given in the weight column is a number between 1.0 (very important) to 0.0 (not important) according to the state of the factors being assessed. And the value given for the rating column is as follows: (Very good $=4)$; $($ Good $=3)$; $($ Good enough $=2)$; $($ Not good $=1)$.

The value of weight for positive strength is given according to the most prominent strategic factors or the size of the strength factor compared to other strategic factors. Whereas the negative weakness weight value is given in the opposite way of strength, where if the weakness is below the average it is given a value of 4 , but if the weakness is above the average is given a value 1 . The IFAS weighting and calculations table can be seen in the following table:

Table 4 - IFAS Matrix

\begin{tabular}{|c|c|c|c|}
\hline Internal Strategic Factors & Weight & Rating & Total Weight $\times$ Rating \\
\hline \multicolumn{4}{|l|}{ Strengths } \\
\hline - A very strategic business location & 0.15 & 4 & 0.6 \\
\hline - $\quad$ Competitive prices & 0.25 & 3 & 0.75 \\
\hline - Having special and quality human resources & 0.065 & 3 & 0.195 \\
\hline - Having a work culture with a family system & 0.025 & 4 & 0.1 \\
\hline - Has a branch & 0.09 & 4 & 0.36 \\
\hline Sub Total & 0.58 & & 2.005 \\
\hline \multicolumn{4}{|l|}{ Weaknesses } \\
\hline - $\quad$ Marketing limitations & 0.1 & 1 & 0.1 \\
\hline - Limitations of raw materials & 0.065 & 3 & 0.195 \\
\hline - $\quad$ Facilities and infrastructure & 0.09 & 2 & 0.18 \\
\hline - Do not have an optimal workforce & 0.055 & 3 & 0.165 \\
\hline - There are not many beauty specialists & 0.11 & 1 & 0.11 \\
\hline Sub Total & 0.42 & & 0.75 \\
\hline TOTAL & 1.00 & & 2.755 \\
\hline
\end{tabular}

From the results obtained in the IFAS matrix above, the strengths havea a subtotal of 2005 while the weaknesses have sub-total of 0.75 .

The external environmental factors are then included in the EFAS table to get the weight and rating that shows the importance of a factor compared to other factors. The value given in the weight column is a number between 1.0 (very important) to 0.0 (not important) according to the state of the factors being assessed. And the value given for the rating column is as follows: $($ Very good $=4)$; $($ Good $=3)$; $($ Good enough $=2)$; $($ Not good $=1)$. 
The following are the external environmental factors that have been analyzed from the Rafa Beauty Clinic:

Table 5 - External Environmental Factors

\begin{tabular}{|c|c|c|c|}
\hline \multicolumn{2}{|c|}{ EXTERNAL ENVIRONMENT } \\
\hline \multicolumn{2}{|c|}{ OPPORTUNITIES } & \multicolumn{2}{c|}{ THREATS } \\
\hline 1 & Good market growth & 1 & Raw material supply \\
\hline 2 & Customer loyalty & 3 & Country economy \\
\hline 3 & Sophisticated technology & 4 & Issues about the content of hazardous substances \\
\hline 5 & Business location environment & 5 & Product licensing policy \\
\hline
\end{tabular}

The weight values for positive opportunities are given according to the most prominent strategic factors or the size of the opportunity factors compared to other strategic factors. Whereas the value of the weight of the negative threat is givenusingf the opposite of the opportunity which if the threat is small or small, then given a value of 4 , but if the threat is greater the value is 1 . The EFAS weighting and calculations table can be seen in the following table:

Table 6 - EFAS Matrix

\begin{tabular}{|c|c|c|c|}
\hline External Strategic Factors & Weight & Rating & Total Weight x Rating \\
\hline \multicolumn{4}{|l|}{ Opportunities } \\
\hline - Good market growth & 0.33 & 4 & 1.32 \\
\hline - $\quad$ Customer loyalty & 0.11 & 4 & 0.44 \\
\hline Sophisticated technology & 0.09 & 4 & 0.36 \\
\hline - $\quad$ Business location environment & 0.055 & 4 & 0.22 \\
\hline - Good relationships with stakeholders & 0.035 & 3 & 0.105 \\
\hline Sub Total & 0.62 & & 2.445 \\
\hline \multicolumn{4}{|l|}{ Threats } \\
\hline - Intense competition & 0.11 & 1 & 0.11 \\
\hline - $\quad$ Raw material supply & 0.09 & 2 & 0.18 \\
\hline - $\quad$ Country economy & 0.025 & 2 & 0.05 \\
\hline - Issues about the content of hazardous substances & 0.015 & 1 & 0.015 \\
\hline Product licensing policy & 0.14 & 1 & 0.14 \\
\hline Sub Total & 0.38 & & 0.495 \\
\hline TOTAL & 1.00 & & 2.94 \\
\hline
\end{tabular}

From the results obtained in the EFAS matrix above, the opportunity factors have a subtotal of 2,445 while the threat factor has a subtotal of 0.495 .

Based on the results obtained from the IFAS and EFAS matrices found in the previous discussion, IFAS and EFAS are included in the matrix of combining IFAS + EFAS as follows:

Table 7 - IFAS + EFAS merging matrix of Rafa Beauty Clinic

\begin{tabular}{|c|c|c|c|}
\hline No. & Strengths & Weight & Weakness \\
\hline 1 & Very strategic business location & 0.6 & Marketing limitations \\
\hline 2 & Competitive prices & 0.75 & Limitations of raw materials \\
\hline 3 & Have special and quality human resources & 0.195 & Facilities and infrastructure \\
\hline 4 & Having a work culture with a family system & 0.1 & Do not have an optimal workforce \\
\hline 5 & Has a branch & 0.36 & There are not many beauty specialists \\
\hline & Subtotal (A) & 2.01 & 0.165 \\
\hline & Opportunities & & 0.11 \\
\hline 1 & Good market growth & 1.32 & Threats \\
\hline 2 & Customer loyalty & 0.44 & Intense competition \\
\hline 3 & Sophisticated technology & 0.36 & Raw material supply \\
\hline 4 & Business location environment & 0.22 & Country economy \\
\hline 5 & Good relationships with stakeholders & 0.105 & 0.11 \\
\hline & Subtotal (C) & 2.45 & 0.18 \\
\hline & Total S+O atau (A)+(C) & 4.45 & Product licensing policy \\
\hline
\end{tabular}

In the matrix table combining IFAS + EFAS above, we can see the comparison that:

Strengths + Opportunities (4.45) > Weaknesses + Threats (1.245) 
Strengths representing strong internal factors and opportunities are environmental factors that support the creation of excellence at the Rafa Beauty Clinic. Strength and Opportunity are positive for the company. So that the total Strengths and Opportunities (S-O) values are positive. Weaknesses represent weak internal factors and threats are environmental factors that do not support the company and even become a threat that drops. So that Weaknesses and Threats $(\mathrm{W}-\mathrm{T})$ are negative. The final value indicated by the SWOT matrix is S-O which is 4.45 , while $W-T$ is -1.245 , so it will form the position of the SWOT quadrant.

From the results of the analysis of internal and external factors of the Rafa Health and Beauty Beauty Clinic using the matrix internal factor analysis strategy (IFAS) and matrix external factor analysis strategy (EFAS), the results of the matrix are poured into the SWOT quadrant diagram. The strategic position shown from the SWOT results is in Quadrant II, which is the position of $W-O$ with an $X$-axis value of -1.245 and axis-Y of 4.45 . The position of $\mathrm{W}-\mathrm{O}$ in quadrant II is a strategy produced through exploiting opportunities by overcoming weaknesses in the Rafa Health and Beauty Beauty Clinic.

So to overcome weaknesses and threats from outside the company, strategic strength and opportunity factors will support the achievement of the way out of the existing problems to get the expected recommendations. And the diagram, and from the previous analysis, the SWOT Quadrant Matrix can be seen as follows:

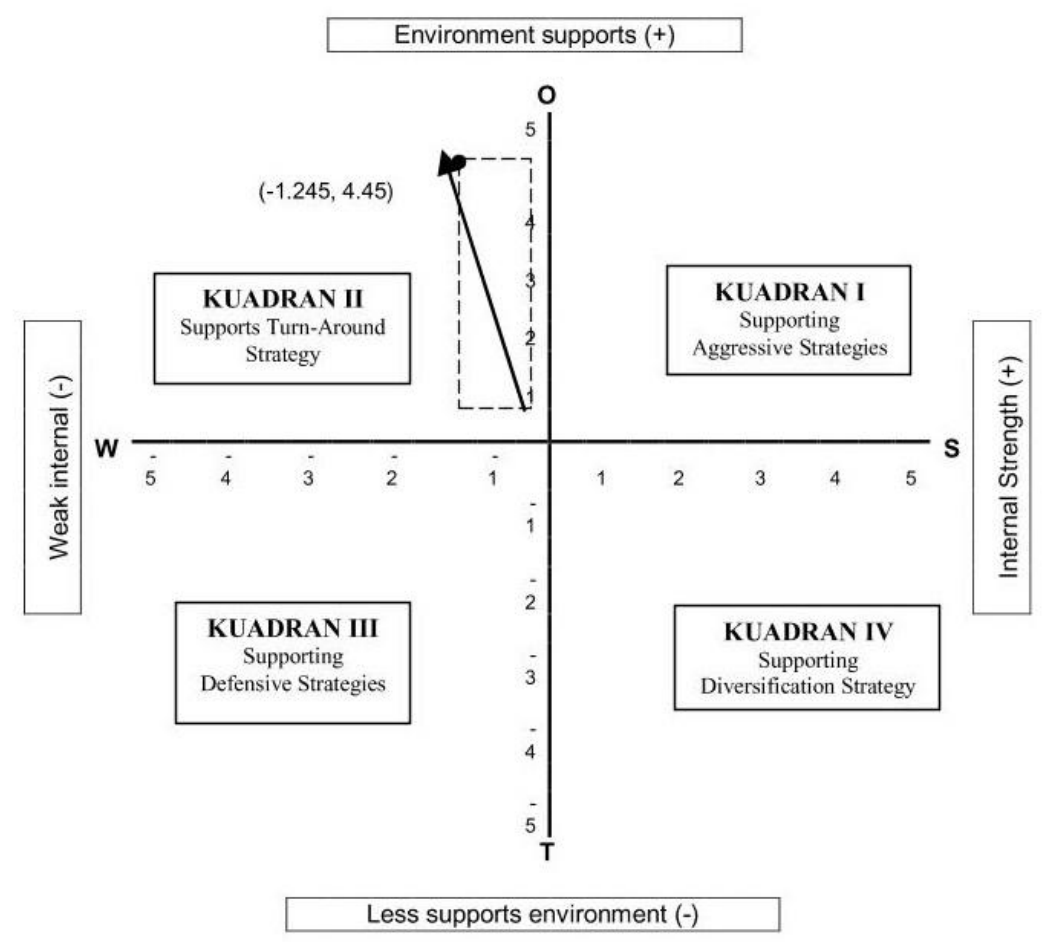

Figure 3 - SWOT Diagram Analysis of Rafa Beauty Clinic

Quadrant I: A favorable situation. the company has strengths and opportunities, so that it can direct all the potential of the internal environment to take advantage of existing opportunities. The strategy that must be applied in this condition is to support an aggressive growth policy, but the clinic is not yet in this position.

Quadrant II: Despite facing various threats, the company still has internal strength. The strategy that must be implemented is to use the power to take advantage of long-term opportunities using diversification strategies. Diversification of the RAFA clinic is to make a different strategy (other than usual) by utilizing the strength of the internal environmen, so that in the future it will enable the creation of opportunities. 
Quadrantt III: companies get opportunities from a large external environment, but on the other hand, always face several obstacles/weaknessess. The company's focus in this position is to minimize the company's internal problems so that it can seize the opportunity from these external conditions well.

Quadrant IV: this position is a very unfavorable situation, the company faces various threats and weaknesses. The strategy that must be used in this position is to defend ourselves to build internal strengths and minimize weaknesses.

From the diagram above, it can be determined that the strategies that need to be implemented to develop the business strategy of the Rafa Health and Beauty Lifestyle Beauty Clinic are Turn-Around Strategies where the Beauty Clinic of Rafa Health and Beauty Lifestyle faces very large market opportunities, but on the other hand faces several obstacles or problems internal. The focus of the strategy is to minimize internal problems so that they can win better market opportunities.

The Rafa Health and Beauty Lifestyle Beauty Clinic is in an industry where the market is growing rapidly, intensive or aggressive strategies are usually the first choice to think about. However, if the Rafa Health and Beauty Lifestyle Beauty Clinic does not have unique competence or competitive advantage, it will be difficult to balance the internal capabilities of the business with existing market opportunities. So to overcome this, the Rafa Health and Beauty Lifestyle Beauty Clinic needs to use several alternatives and more strategic strategies based on the results of the SWOT quadrant analysis which results in a reference to using a turn-around strategy. This is to find solutions to internal problems and to create a strategy for developing the Rafa Health and Beauty Beauty Clinic so that it can be superior to competitors and win the market.

Based on the results of the research conducted, the Rafa Health and Beauty Lifestyle Beauty Clinic is a Beauty Service in the criteria for the level of realization, namely goods service, according to (Stephen P. Robins, 2012) Strategic management is important because it can make a difference in how well an organization performs and relates to reality that organizations of all types and sizes face a changing situation. Rafa Beauty Clinic has been able to compete with its competitors and has greater opportunities because it can reduce prices and provide good and optimal services to consumers.

Based on the results of the external and internal environmental analysis of this business using the EFAS matrix method (External Factors Analysis Summary) and the IFAS (Internal Factors Analysis Summary) matrix showing that the Rafa Beauty Clinic on strength has a total of 2,005 while the weaknesses has a total of 0.75 , and opportunity factors have a total of 2,445 while the threat factor has a total of 0.495 . Which then all the sub-totals are poured into the SWOT diagram and produce the Rafa Beauty Clinic in Quadrant II, that is, the right strategy implemented is a turn-around strategy (Retrenchment) that is designed to strengthen the basic competencies of a unique organization.

According to (Banister, 2006) Companies that are in Quadrant II need to evaluate their current approach to the market seriously. Even though their company is growing, they are unable to compete effectively and need to determine why the company's current approach is ineffective and how the company can change in the best way to improve its competitiveness. Because Quadrant II companies are in industries whose markets are growing rapidly, so several strategies can be used, namely market development, market penetration, product development, and horizontal diversification. According to (Banister, 2006) Companies that are in Quadrant II need to evaluate their current approach to the market seriously. even though their company is growing, they are unable to compete effectively and need to determine why the company's current approach is ineffective and how the company can change in the best way to improve its competitiveness. Because Quadrant II companies are in industries whose markets are growing rapidly, so several strategies can be used, namely market development, market penetration, product development, and horizontal diversification.

Based on the results of the initial observation, it was found that the phenomenon of competitive behavior among the fashion industry specifically the beauty clinic was very unique. There is competition marked by the many competitive actions carried out by beauty 
clinics or skin care companies, such as price cuts, the emergence of sophisticated tools that support skincare clinics, the existence of special programs that attract the hearts of consumers, and massive promotions.

Furthermore, in the results of the SWOT matrix analysis, the Rafa Beauty Clinic business produces several alternative strategies, namely: Increasing promotional activities in efforts to develop and penetrate markets; improve product quality to obtain customer loyalty to be able to repeat orders; Rafa Beauty Clinics must be selective in choosing suppliers that offer great benefits for both parties; Make or add services and facilities in efforts to horizontal diversification; Train new employees and set standards of expertise for employees to be able to compete based on HR aspects, then recruit professional beauty specialists; add a network of raw material suppliers to improve production capacity and then develop products by utilizing technology to meet market demands.

The alternative strategy is designed in such a way as to increase the income of the Rafa Beauty Clinic so that it can develop into a larger business. Thus, if the Rafa Beauty Clinic has implemented a strategy based on the advice given by the SWOT matrix, it will be able to create a competitive advantage. Special attention also lies in the Long-term strategy so that Rafa Beauty Clinic can create competitive advantage continuously.

\section{CONCLUSION}

The Rafa Health and Beauty Lifestyle Beauty Clinic is in an industry where the market is growing rapidly, intensive or aggressive strategies are usually the first choice to think about. However, if the Rafa Health and Beauty Lifestyle Beauty Clinic does not have unique competence or competitive advantage, it will be difficult to balance the internal capabilities of the business with existing market opportunities. So to overcome this, the Rafa Health and Beauty Lifestyle Beauty Clinic needs to use several alternatives and more strategic strategies based on the results of the SWOT quadrant analysis which results in a reference to using a turn-around strategy.

Based on the results of research through SWOT analysis (Strengths, Weaknesses, Opportunities, and Threats Analysis), the researcher will conclude the conditions and environmental factors faced by the Rafa Health and Beauty Clinic, and how to compete. The conditions of the internal environmental factors of the Beauty Clinic Rafa health and Beauty Lifestyle include Strength (Strength), including a very strategic business location, Competitive prices, Special and qualified human resources, Having a work culture with a family system, Having branches. Whereas in the aspect of weakness, among others are the limitations of marketing, Limited raw materials, Facilities, and infrastructure, Not yet having an optimal workforce, Beauty specialist experts have not supported Rafa much.

The conditions of the external environmental factors of the Beauty Clinic Rafa health and Beauty Lifestyle include the opportunities which include good market growth, customer loyalty, technological sophistication, business location environment, good relationships with stakeholders. Then the weaknesses are a tight competition, raw material supply, the country's economy, dangerous substance content issues, product licensing policies.

Based on the research that has been done on the efforts of the Beauty Clinic. So the researcher provides recommendations that can be used as input for strategic planning. there are two recommendations given, namely for short and long term plans, namely as follows:

- Short-term alternative strategies include; Increase promotional activities regularly through online media, develop products by utilizing technology to meet market desires, add a network of suppliers of raw materials to improve services, recruit professional beauty specialists.

- Long-term alternative strategies include; Improve product quality to obtain customer loyalty, selectively choose suppliers that offer large profits, add or provide facilities for customers, train new employees and set standards of employee expertise. 


\section{REFERENCES}

1. Ansoff, H. I. (1968). Corporate strategy: an analytic approach to business policy for growth and expansion. Pelican library of business and management.

2. Ansoff, H. I. (2005). Strategic Management. Management, 29, 1-56.

3. Ansoff, I. (1965). Concept of Strategy. In Corporate Strategy.

4. Assauri, S. (2011). Manajemen Pemasaran Dasar Konsep dan Strategi. PT RajaGrafindo Persada, Jakarta.

5. Banister, D. (2006). Michael Banister (1918-2006). Transport Reviews, 26(5), 535.

6. Bryson, J. M. (1988). A strategic planning process for public and non-profit organizations. Long Range Planning.

7. Chang, T. Y., \& Horng, S. C. (2010). Conceptualizing and measuring experience quality: The customer's perspective. Service Industries Journal.

8. Corrocher, N., \& Guerzoni, M. (2009). Product variety and price strategy in the ski manufacturing industry. Journal of Evolutionary Economics.

9. David, F. R. (2011). Strategic Management: Concepts and Cases (Thirteenth Edition). Prentice Hall.

10. David, F. R., \& Carolina, S. (2011). Strategic Management Concepts and Cases. Zeitschrift für Personalforschung.

11. David, F. R., \& David, F. R. (2017). Strategic Management A Competitive Advantage Approach Concepts and cases. Pearson.

12. Dey, P. K., Clegg, B. T., \& Bennett, D. J. (2010). Managing enterprise resource planning projects. Business Process Management Journal.

13. Fleisher, C., \& Bensoussan, B. (2007). McKinsey 7S Framework. Financial Times.

14. Ginsberg, A., \& Venkatraman, N. (2011). Contingency Perspectives if Organizational Strategy: A Critical Review of the Empirical Research. Academy of Management Review.

15. Gunawan, I. (2013). Metode penelitian kualitatif. Jakarta: Bumi Aksara.

16. Haines, S. (2010). Revolutionary Changen The Systems Thinking Approach to Strategic Planning and Management.

17. Kaplan, R. S. (2005). Strategy \& Leadership How the balanced scorecard complements the McKinsey 7-S model How the balanced scorecard complements the McKinsey 7-S model. Strategy \& Leadership Strategic Outsourcing: An International Journal Iss Management Decision Iss Management Decision.

18. Kerzner, H. (2001). Strategic Planning for Project Management Using a Project Management Maturity Model. Assessment.

19. Kerzner, H. (2004). Strategic planning for a project office. IEEE Engineering Management Review.

20. Nickols, F. (2016). Strategy, Strategic Planning, Strategic Thinking, Strategic Management. Nickols.

21. Pearce, J., \& Robinson, A. (2011). Strategic management: Formulation, implementation \& control. In Mcgraw Hill Higher Education; 12th Revised edition,2011,.

22. Porter, M. E. (1980). Competitive Strategy. Techniques for Analyzing Industries and Competitors, $1(2), 396$.

23. Porter, M. E. (1996). What Is Strategy? Harvard Business Review, 74(6), 61-78.

24. Porter, M. E. (1997). Competitive strategy. Measuring Business Excellence.

25. Porter, M. E. (2008a). Strategy Strategy the Five Competitive. Harvard Business Review, 86(January), 78-94.

26. Porter, M. E. (2008b). The five competitive forces that shape strategy. Harvard Business Review.

27. Rangkuti, F. (2013). Teknik Membedah Kasus Bisnis Analisis SWOT Cara Perhitungan Bobot, Rating, dan OCAI. PT. Gramedia Pustaka Utama. Jakarta.

28. Rangkuti, F. (2015). Personal SWOT Analysis. Free-Managment-Ebooks.

29. Ravanfar, M. M. (2015). Analyzing Organizational Structure based on 7s model of McKinsey. International Journal of Academic Research in Business and Social Sciences, $5(5)$. 
30. Ravanfar, M. M. (2017). Analyzing Organizational Structure based on 7s model of McKinsey. International Journal of Academic Research in Business and Social Sciences.

31. Rulmet, R. (1984). Competitive strategic management. In Towards a strategic theory of the firm.

32. Rumelt, R. P. (2012). Good Strategy/Bad Strategy: The Difference and Why It Matters. Strategic Direction.

33. Rumelt, R. P., Schendel, D., \& Teece, D. J. (1991). Strategic management and economics. Strategic Management Journal, 12(2 S), 5-29.

34. Savkin, A. (2015). 7-S Framework - Get a Big Picture of a Problem and Have Insights to Achieve Desired Results. Business Scorecard.

35. Simons, R. (1994). How new top managers use control systems as levers of strategic renewal. Strategic Management Journal.

36. Slater, S. F., \& Narver, J. C. (1994). Does Competitive Environment Moderate the Market Orientation-Performance Relationship? Journal of Marketing.

37. Sugiono. (2016). Metode penelitian kombinasi. In Metode penelitian kombinasi.

38. Sugiyono. (2010). Metode Penelitian Kombinasi (Mixed Methods). Bandung: Alfabeta.

39. Teece, D. J. (2010). Business models, business strategy and innovation. Long Range Planning, 43(2-3), 172-194.

40. Thune, S. S., \& House, R. J. (1970). Where long-range planning pays off Findings of a survey of formal, informal planners. Business Horizons.

41. Tunggal AW. (2009). Supply Chain Management (Manajemen Rantai Pasokan). Jakarta (ID): Harvarindo.

42. Ward, J., \& Peppard, J. (2002). Strategic planning for information systems / John Ward and Joe Peppard. Wiley Series in Information Systems.

43. Waterman, R. H., Peters, T. J., \& Phillips, J. R. (1980). Structure is not organization. Business Horizons.

44. Wheelen, T. L., \& Hunger, J. D. (2010). Basic concepts of strategic management. Concepts in Strategic Management and Business Policy. 